MoniKa SAdowsKa*

\title{
DOWODZENIE ZWIĄZKU PRZYCZYNOWO-SKUTKOWEGO W SPRAWACH O ZAKAŻENIA SZPITALNE
}

Związek przyczynowo-skutkowy oznacza przyczynowe powiązanie przesłanki szkody oraz zdarzeń prawnych wywołujących szkodę, czyli działania i zaniechania zobowiązanego ${ }^{1}$. Jest elementem koniecznym dla ustalenia odpowiedzialności odszkodowawczej i powstania obowiązku naprawienia szkody.

Związek przyczynowo-skutkowy pomiędzy zdarzeniem a szkodą powinien być pewny. Jednakże w sprawach medycznych, do których niewątpliwie należy zaliczyć procesy o zakażenia szpitalne, wymaganie całkowitej pewności byłoby trudne. Jest to spowodowane często dużym upływem czasu od zdarzenia do ujawnienia się zakażenia lub jego skutków, właściwościami procesów biologicznych organizmu człowieka, stopniem rozwoju technologii medycznych, warunkami organizacyjnymi podmiotów leczniczych. Nie bez znaczenia jest także standaryzacja świadczonych usług medycznych, w tym jakość prowadzenia dokumentacji dotyczącej procesu leczenia pacjenta oraz dokumentowanie działań związanych z bezpieczeństwem sanitarnym, m.in. opracowanie mechanizmów mających na celu zapobieganie zakażeniom oraz wykrywanie ich, zgłaszanie i leczenie.

Wobec trudności dowodowych, jak też dla ochrony uzasadnionych interesów poszkodowanych w orzecznictwie i piśmiennictwie coraz częś-

* Dr nauk med., Pracownia Technik Diagnostycznych, Wydział Nauk o Zdrowiu, Uniwersytet Medyczny w Lublinie, monika.sadowska@umlub.pl.

1 A. Rzetecka-Gil, Kodeks cywilny. Komentarz. Zobowiazania - część ogólna, LEX/el 2011, uwaga 3 do art. 361. 
ciej uważa się wymóg wykazania przesłanki związku przyczynowego za spełniony, jeżeli poszkodowany udowodnił bardzo wysoki stopień prawdopodobieństwa, że zdarzenie i szkoda pozostają w adekwatnym związku przyczynowym ${ }^{2}$. Adekwatny związek przyczynowo-skutkowy istnieje wówczas i tylko wówczas, gdy w łańcuchu kolejnych przyczyn i skutków mamy do czynienia tylko z takimi przyczynami, które normalnie wywołują dane skutki ${ }^{3}$. Jest on kategorią obiektywną i należy pojmować go jako wynikające $\mathrm{z}$ doświadczenia życiowego oraz wiedzy naukowej i obiektywne powiązanie ze sobą dwóch zjawisk: przyczyny i skutku4. Adekwatny związek przyczynowo-skutkowy może być bezpośredni, lecz także pośredni, przy czym ocena, czy skutek pozostaje w granicach normalności, powinna opierać się na całokształcie okoliczności sprawy, wynikać z doświadczenia życiowego, wiedzy naukowej i specjalnej ${ }^{5}$. Wiedza specjalna będzie szczególnie istotna w sprawach zawiłych, w których normalność nie jest dla laika ewidentna ${ }^{6}$.

W orzecznictwie Sądu Najwyższego wskazano, że w procesie nie da się przeprowadzić dowodu „bez reszty”. Jest to częstokroć utrudnione aktualnym stanem wiedzy medycznej, która nie zawsze jest w stanie dać stanowczą odpowiedź na każde pytanie. W takiej sytuacji sąd może, po rozważeniu całokształtu okoliczności sprawy, uznać dowód za przeprowadzony, mając na uwadze wysoki stopień prawdopodobieństwa ${ }^{7}$. Dla oceny istnienia normalnego związku przyczynowego nie ma znaczenia, czy dane zdarzenie może być przez sprawce przewidziane, gdyż przewidywalność jest kategorią winy, a nie związku przyczynowego, który jest okolicznością obiektywną 8

${ }^{2}$ M. Nesterowicz, Odpowiedzialność cywilna zakładu leczniczego za bezpieczeństwo pacjenta podczas hospitalizacji, PiP 2001, nr 3, s. 40 i n.

3 Wyrok Sądu Apelacyjnego w Krakowie z dnia 3 marca 2016 r., I ACa 1661/15, LEX nr 2004524.

${ }^{4}$ M. Nesterowicz, Prawo medyczne. Komentarze i glosy do orzeczeń sądowych, Warszawa 2014, s. 142.

${ }^{5}$ Wyrok Sądu Apelacyjnego w Poznaniu z dnia 10 sierpnia 2011 r., I ACa 1082/10, LEX nr 898633 oraz wyrok Sądu Apelacyjnego w Warszawie z dnia 29 marca 2011 r., I ACa 917/10, LEX nr 836914.

${ }^{6}$ Wyrok Sądu Apelacyjnego w Szczecinie z dnia 28 kwietnia 2015 r., I ACa 323/13, LEX nr 1782045.

7 Wyrok Sądu Najwyższego z dnia 5 lipca 1967 r., I PR 74/67, OSN z 1968 r., nr 2, poz. 26.

${ }^{8}$ M. Śliwka, Ciężar dowodu w procesach medycznych - między domniemaniami faktycznymi a dowodem prima facie II. Domniemania faktyczne a dowód prima facie, "Archiwum Medycyny Sądowej i Kryminologii" 2004, nr 1, s. 61. 
Zważyć należy, że nie ma żadnych podstaw do twierdzenia, iż w tzw. sprawach medycznych na stronie powodowej nie ciąży obowiązek wykazania wszystkich przesłanek odpowiedzialności odszkodowawczej pozwanego, w tym związku przyczynowo-skutkowego. Biorąc jednak pod uwage, że w tego rodzaju procesach wykazywanie przez powoda wszystkich etapów związku przyczynowego pomiędzy zdarzeniem wskazywanym jako sprawcze a szkodą może być nader utrudnione, a nawet niemożliwe, orzecznictwo dopuściło tzw. dowód prima facie oparty na konstrukcji domniemań faktycznych (art. 231 k.p.c.). Domniemanie faktyczne polega na tym, że sąd na podstawie ustalenia jednych faktów wnioskuje o istnieniu innych. Sąd ma w takim wypadku zupełną swobodę wnioskowania na podstawie całokształtu okoliczności ujawnionych w toku postępowania dowodowego. Wnioskowanie musi być jednak poprawne z punktu widzenia zasad logiki. Możliwe jest więc dokonanie ustalenia na podstawie domniemania faktycznego wówczas, gdy wniosek taki nasuwa się z pewnością lub ze szczególnie dużą dozą prawdopodobieństwa, natomiast wniosek przeciwny nie ma $\mathrm{w}$ danych okolicznościach żadnego uzasadnienia bądź też jest wysoce mało prawdopodobny ${ }^{9}$. Domniemanie faktyczne nie powinno być także sprzeczne z określonymi zasadami doświadczenia życiowego ${ }^{10}$.

Związek przyczynowo-skutkowy między zachowaniem pozwanego podmiotu leczniczego a szkoda, $\mathrm{w}$ postaci pogorszenia stanu zdrowia pacjenta, nie musi być zatem ustalony w sposób pewny, wystarczy wysoki stopień prawdopodobieństwa istnienia takiego związku, a w przypadku wielości możliwych przyczyn - przeważające prawdopodobieństwo związku przyczynowego szkody z jedną z tych przyczyn ${ }^{11}$. Wskazany dowód jest więc dowodem pośrednim, który nie zmienia rozkładu ciężaru dowodu. Na podstawie domniemania faktycznego może być ustalona zarówno wina pracownika medycznego, o ile brak jest dowodu przeciwnego, jak i istnienie związku przyczynowego między zaniedbaniami personelu podmiotu leczniczego a pogorszeniem stanu zdrowia lub śmiercią pacjenta, chyba że istnieją podstawy do wniosku, iż zasady medycyny

${ }_{9}$ T. Ereciński, [w:] T. Ereciński (red.), Kodeks postępowania cywilnego. Komentarz, t. I, Postępowanie rozpoznawcze, Warszawa 2012, uwaga 2 do art. 231 k.p.c.

${ }^{10}$ T. Ereciński, [w:] T. Ereciński (red.), Kodeks..., uwaga 3 do art. 231 k.p.c.

11 Wyroki Sądu Najwyższego: z dnia 5 lipca 1967 r., I PR 74/67, OSN z 1968 r., nr 2, poz. 26 i z dnia 7 czerwca 1969 r., II CR 165/69, OSPiKA z 1969 r., nr 7-8, poz. 155, z dnia 13 czerwca 2000 r., V CKN 34/00, niepubl., z dnia 17 maja 2007 r., III CSK 429/06, niepubl. 
związek ten wyłączają ${ }^{12}$. Domniemanie faktyczne może być podstawą ustaleń o tyle tylko, o ile stanowi wniosek logiczny z prawidłowo ustalonych faktów stanowiących jego przesłankę ${ }^{13} \mathrm{i}$ wchodzi w rachubę tylko w braku bezpośrednich środków dowodowych ${ }^{14}$.

Konstrukcja reguł wnioskowania prima facie jest sporna w nauce pra$w^{15}$. Zdaniem jej przeciwników stosowanie dowodów prima facie tylko ułatwia dowodzenie, nie dając pewności co do zajścia pewnych okoliczności, a jedynie je uprawdopodabnia. Jest to znacząca różnica w stosunku do domniemania faktycznego, wymagającego pewności wniosków, na których zostało oparte ${ }^{16}$. Ponadto prezentowany jest pogląd, że idea dowodu prima facie wyczerpuje się w zasadzie swobodnej oceny dowodów oraz domniemań faktycznych i nie ma potrzeby wprowadzania pozaustawowej nomenklatury do polskiego procesu cywilnego ${ }^{17}$. Jednocześnie podnosi się, że stosując omawiany sposób dowodzenia, nie da się uniknąć manipulacji ustawowo określonym rozkładem ciężaru dowodu, czego skutkiem jest przeniesienie ciężaru dowodu na „silniejszą" stronę postępowania, jaką jest podmiot leczniczy. Stąd H. Dolecki podkreśla, że stosowanie dowodu prima facie winno być ograniczone jedynie do sytuacji wyjątkowych, w których nie ma możliwości przeprowadzenia dowodu w inny sposób ${ }^{18}$.

Z kolei zdaniem zwolenników stosowania dowodu prima facie dowód ten podlega swobodnej ocenie dokonywanej przez sąd jak każdy inny dowód na podstawie całego zebranego w sprawie materiału. Stąd nie można twierdzić, że jest to dowód niepotrzebny czy też w sposób arbitralny faworyzujący jedną ze stron (najczęściej poszkodowanego), gdyż strona przeciwna będzie nadal miała możliwość przeprowadzenia do-

12 Wyrok Sądu Najwyższego z dnia 11 stycznia 1972 r., I CR 516/71, OSNCP, nr 9, poz. 159.

${ }^{13}$ Wyrok Sądu Najwyższego z dnia 22 stycznia 1998 r., II UKN 465/97, OSNP z 1999 r., nr 1, poz. 24.

${ }^{14}$ Wyrok Sądu Najwyższego z dnia 19 lutego 2002 r., IV CKN 718/00, niepubl.

15 B. Janiszewska, Praktyka sądowa w sprawach cywilnych o zakażenia szpitalne (dowodzenie przestanek odpowiedzialności oraz roszczenia przystugujace pacjentowi - część I), „Prawo i Medycyna", http://www.prawoimedycyna.pl/index.php?str=artykul\&id=225 [dostęp: 10.09.2017 r.].

${ }^{16}$ M. Białkowski, Dowód prima...

17 M. Sośniak, Zagadnienie zwiazku przyczynowego a dowód prima facie w procesach lekarskich, Księga pamiątkowa ku czci Kamila Stefki, Warszawa-Wrocław 1967, s. 342-343.

${ }_{18}$ M. Białkowski, Dowód prima... 
wodu przeciwnego na poparcie swoich twierdzeń ${ }^{19}$. Może wnioskować o przeprowadzenie dowodu z dokumentów wykazujących brak innych przypadków zakażeń czy też potwierdzających stosowane w podmiocie leczniczym procedury sanitarno-epidemiologiczne celem wykazania, że ryzyko wystąpienia zakażenia jest minimalne ${ }^{20}$. Ponad to zdaniem H. Doleckiego stosowanie tego dowodu, choć niepozbawione wątpliwości, ani nie zmienia reguł odpowiedzialności, ani nie doprowadza do nadużyć i nieprawidłowości, a "łagodzi” trudności dowodowe ${ }^{21}$.

Z kolei M. Nesterowicz podkreśla, że dowód prima facie jest nadal tylko jednym z dowodów, które podlegają ocenie sądu, o czym nie należy zapominać ${ }^{22}$. Ponadto, zdaniem M. Nesterowicza, przeprowadzenie dowodu prima facie jest uwarunkowane spełnieniem kilku przesłanek:

- należy wykazać, że zdarzenie nie miałoby miejsca, gdyby pozwany dołożył należytej staranności;

- istnieje duże prawdopodobieństwo, że zdarzenie nastąpiłoby w czasie, gdy powód znajdował się pod kontrolą pozwanego;

- zachowanie powoda było bierne, tak by nie można było wyprowadzić wniosku, że sam sobie wyrządził szkodę;

- przyczyny szkody nie mogą być ustalone za pomocą pewniejszych środków dowodowych;

- z okoliczności sprawy widoczne jest dopuszczenie się niedbalstwa, rzecz mówi sama za siebie (res ipsa loquitur - rzecz mówi sama za siebie $)^{23}$.

Przepis art. 278 k.p.c. nakłada na sąd obowiązek skorzystania z opinii biegłego, jeżeli dla rozstrzygnięcia sprawy wymagane są wiadomości specjalne. Jednakże zadaniem biegłego nie jest ustalenie stanu faktycznego sprawy, lecz osąd o okolicznościach faktycznych, stanach i zdarzeniach przy uwzględnieniu zebranego i udostępnionego mu materiału sprawy, na podstawie posiadanego przez biegłego zasobu wiedzy, wykraczającego poza zakres wiadomości i doświadczenia życiowego ogółu osób inteligentnych i ogólnie wykształconych ${ }^{24}$.

19 M. Białkowski, Dowód prima...

${ }^{20}$ B. Janiszewska, Praktyka sadowa...

${ }^{21}$ H. Dolecki, [w:] H. Dolecki, T. Wiśniewski (red.), Kodeks postępowania cywilnego. Komentarz, t. I, art. 1-366, Lex 2013, uwaga 12 do art. 231.

${ }^{22}$ M. Nesterowicz, Ciężar dowodu winy w procesach lekarskich, PiP 1968, nr 4-5, s. 682.

${ }^{23}$ M. Śliwka, Ciężar dowodu..., s. 61.

${ }^{24}$ T. Demendecki, [w:] A. Jakubecki (red.), Kodeks postępowania cywilnego, t. I, Komentarz do art. 1-729, Warszawa 2017, uwaga do art. 278 k.p.c. 
Nie można jednak zapominać, że to sąd, a nie biegli, musi stwierdzić, czy istnieje związek przyczynowo-skutkowy lub że go brak, i uzasadnić swoje stanowisko na podstawie materiału procesowego i zasad doświadczenia życiowego ${ }^{25}$. Stąd za niedopuszczalne uznaje się dokonywanie przez biegłego ustaleń stanu faktycznego, co należy do kompetencji sądu ${ }^{26}$. Biegły powinien wypowiedzieć się co do okoliczności, wyjaśniając zaistniałe zdarzenia, stany, zjawiska w sporządzanej opinii, z punktu widzenia posiadanych wiadomości fachowych i doświadczenia zawodowego ${ }^{27}$.

Można by zadać pytanie, co w sytuacji, kiedy skład orzekający dysponuje wiedzą $w$ danej dziedzinie - czy w związku z tym sąd mógłby pominać dowód z opinii biegłego? Judykatura w tym kontekście prezentuje stanowisko jednoznaczne, a mianowicie, gdy rozstrzygnięcie sprawy wymagałoby wiadomości specjalnych, niedopuszczalne jest pominięcie dowodu z opinii biegłych, choćby ktokolwiek ze składu orzekającego takie wiadomości posiadał. Inaczej, strona byłaby pozbawiona możności stawiania pytań i krytyki określonego poglądu, a ponadto prowadziłoby to do niedopuszczalnego połączenia funkcji sędziego i biegłego ${ }^{28}$. Jednakże własne wiadomości specjalne mogą sądowi ułatwić ocenę opinii biegłego $^{29}$, przy czym uznanie opinii za nieprzekonująca, z powołaniem się przez sąd jedynie na własne wiadomości specjalne, stanowi przekroczenie granic swobodnej oceny dowodów ${ }^{30}$.

W sprawach o zakażenia szpitalne biegły w sporządzanej opinii niejednokrotnie stara się określić istnienie związku czasowego między leczeniem $\mathrm{w}$ podmiocie leczniczym a wystąpieniem u pacjenta cech zakażenia, przy uwzględnieniu typowego okresu wylęgania choroby. Ma to niebagatelne znaczenie dla ustalenia, czy zaistniałe zdarzenie jest zakażeniem szpitalnym. Zgodnie $\mathrm{z}$ definicją normatywną zakażenie szpitalne jest to zakażenie, które wystąpiło w związku z udzielaniem świadczeń zdrowotnych w przypadku, gdy choroba:

- nie pozostawała $\mathrm{w}$ momencie udzielania świadczeń zdrowotnych w okresie wylęgania albo

${ }^{25}$ M. Nesterowicz, Prawo medyczne, Toruń 2013, s. 109.

26 T. Demendecki, [w:] A. Jakubecki (red.), Kodeks..., uwaga do art. 278 k.p.c.

27 T. Ereciński, [w:] T. Ereciński (red.), Kodeks..., uwaga 2 do art. 278 k.p.c.

${ }^{28}$ T. Demendecki, [w:] A. Jakubecki (red.), Kodeks..., uwaga do art. 278 k.p.c.

${ }^{29}$ T. Ereciński, [w:] T. Ereciński (red.), Kodeks..., uwaga 1 do art. 278 k.p.c.

${ }^{30}$ T. Ereciński, [w:] T. Ereciński (red.), Kodeks..., uwaga 22 do art. 278 k.p.c. 
- wystąpiła po udzieleniu świadczeń zdrowotnych w okresie nie dłuższym niż najdłuższy okres jej wylęgania ${ }^{31}$.

Zdaniem Sądu Apelacyjnego w Łodzi (wyrok z dnia 6 listopada 2014 r., I ACa 621/14), termin „,zakażenie szpitalne" oznacza jedynie związek funkcjonalny infekcji z pobytem chorego w danej placówce medycznej, natomiast czynnik wywołujący to zakażenie nie musi mieć żadnego związku z funkcjonowaniem szpitala lub sposobem organizacji opieki medycznej ani zaniedbaniami ze strony personelu ${ }^{32}$. Ponadto $w$ piśmiennictwie zwraca się uwagę na problematykę występowania zakażeń endogennych, spowodowanych własną florą bakteryjną skóry lub błon śluzowych pacjenta, w kontekście odpowiedzialności odszkodowawczej podmiotu leczniczego ${ }^{33}$. Wystąpienie zakażenia szpitalnego, w tym endogennego, nie przesądza o obciążeniu świadczeniodawcy skutkami niepowodzenia medycznego, zwłaszcza przy współistnieniu braku odporności ${ }^{34}$ czy też podejmowaniu przez pacjenta nieracjonalnych decyzji niweczących proces leczenia ${ }^{35}$.

Nie można zakładać, iż zakażenie pacjenta w szpitalu w toku leczenia w każdym przypadku oznacza zaniedbanie w zakresie bezpieczeństwa sanitarnego, na co zwrócił uwagę Sąd Najwyższy w wyroku z dnia 14 stycznia 2016 r., I CSK 1031/14 ${ }^{36}$. W okolicznościach przedmiotowej sprawy nie istniały dowody, które pozwalałyby przyjąć co najmniej wysokie prawdopodobieństwo, że do zakażenia szpitalnego doszło z przyczyn obciążających podmiot leczniczy. W uzasadnieniu wyjaśniono, że zakażenia rany pooperacyjnej wiążą się ściśle z przyjętą metodą leczenia, tj. metodą leczenia operacyjnego, a także biologicznymi cechami pacjenta. Drobnoustroje wywołujące zakażenie mogą pochodzić ze środowiska szpitalnego z powodu np. źle wyjałowionego sprzętu, z rąk personelu lub osób odwiedzających. Źródłem zakażenia może być również flora bakteryjna sko-

${ }^{31}$ Ustawa z dnia 5 grudnia 2008 r. o zapobieganiu oraz zwalczaniu zakażeń i chorób zakaźnych u ludzi, tekst jedn., Dz.U. z 2016 r. poz. 1866.

${ }^{32}$ Wyrok Sądu Apelacyjnego w Łodzi z dnia 6 listopada 2014 r., I ACa 621/14, LEX nr 1623923.

${ }^{33}$ D. Wąsik, N. Wąsik, B. Sygit, M. Dubiel, Zakażenie endogenne a odpowiedzialność cywilna szpitala - studium przypadku, "Archiwum Medycyny Sądowej i Kryminologii” 2014, 64(3), s. 149.

${ }^{34}$ Wyrok Sądu Apelacyjnego w Warszawie z dnia 3 czerwca 2014 r., I ACa 1494/13, LEX nr 1493819.

${ }^{35}$ Wyrok Sądu Apelacyjnego w Szczecinie z dnia 10 kwietnia 2014 r., I ACa 22/14, LEX nr 1466926.

36 Wyrok Sądu Najwyższego z dnia 14 stycznia 2016 r., I CSK 1031/14, LEX nr 1991132. 
lonizowana na skórze pacjenta. Na wzrost ryzyka zakażenia wpływają też czynniki związane bezpośrednio ze stanem pacjenta, np. jego wiekiem, obniżoną odpornościa, stanem odżywienia, współistnieniem innych chorób. Poszkodowany nie wykazał związku przyczynowego pomiędzy zakażeniem go a występowaniem zaniedbań personelu medycznego $\mathrm{w}$ toku czynności leczniczych. Zaniedbań tych nie uprawdopodobniła także opinia biegłego, z której wynikało, że przyczyna zakażenia powoda może być inna niż zaniedbania personelu, w szczególności kolonizacja bakterii szczepów na skórze pacjenta, jego ogólny stan zdrowia, a przede wszystkim - brak odporności. W ocenie sądu nie mógł mieć znaczenia przesądzającego fakt, że w danej placówce inny pacjent został zakażony gronkowcem. Reasumując, powód nie podjął próby skonkretyzowania i udowodnienia błędów personelu medycznego i pomocniczego.

Szczególne trudności w ustalaniu czasu zakażenia występują w przypadkach, gdy zakażenie przebiega bezobjawowo do czasu ujawnienia się nosicielstwa, niejednokrotnie w sposób przypadkowy ${ }^{37}$. Sąd Najwyższy w wyroku z dnia 4 listopada 2005 r. (V CK 182/05) orzekł, że przyjęcie związku przyczynowego między pobytem pacjenta w szpitalu a doznanym zakażeniem możliwe jest przy ustaleniu prawdopodobieństwa wysokiego stopnia. Ocena, czy zachodzi związek przyczynowy, nie może być jednak oderwana od konkretnego stanu faktycznego. Im dłuższy czas upływa między pobytem pacjenta w szpitalu a wystąpieniem objawów zakażenia, tym mniejsze prawdopodobieństwo, że leczenie szpitalne było przyczyną tego zakażenia ${ }^{38}$.

W swoich opiniach dotyczących zakażeń szpitalnych biegli, opierając się na posiadanej wiedzy i doświadczeniu zawodowym, starają się ustalić, czy prawdopodobieństwo zakażenia było wysokie, czy nie. Nie wystarczy stwierdzenie, że związek przyczynowy jest możliwy. Konieczne jest jego uprawdopodobnienie, np. poprzez wykazanie, że na określonym oddziale w podmiocie leczniczym zanotowano przypadki zakażenia szpitalnego, czy też wskazanie na protokoły pokontrolne wykazujące problemy podmiotu leczniczego $\mathrm{z}$ zaopatrzeniem $\mathrm{w}$ ręczniki jednorazowe, mydło, środki czystości, czy też zwrócenie uwagi na konieczność systematycznego szkolenia pracowników medycznych pod względem przestrzegania procedur mycia rąk, dezynfekcji, zmiany rękawiczek, prawidłowego po-

${ }^{37}$ I. Wrześniewska-Wal, Postępowanie dowodowe w zakażeniach szpitalnych, „Medical Maestro Magazine" 2015, nr 1, s. 98.

${ }^{38}$ Wyrok Sądu Najwyższego z dnia 4 listopada 2005 r., V CK 182/05, LEX nr 180901. 
bierania materiału do badań ${ }^{39}$. Ponadto aktywne monitorowanie zakażeń i ryzyka zakażenia to priorytetowy standard współczesnej medycyny, stanowiący jednocześnie źródło informacji o stopniu bezpieczeństwa sanitarnego pacjentów w podmiocie leczniczym ${ }^{40}$.

Nie bez znaczenia są też zeznania samych poszkodowanych opisujące, że „zarówno na salach i w toaletach nie było czysto, nie było również podziału na tzw. czysty i brudny oddział. Wszyscy leżeli na tej samej sali, także pacjenci, którzy mieli rany z wydzielającą się z nich ropą"41. Dlatego też $\mathrm{w}$ takiej sytuacji, jeżeli podmiot leczniczy twierdzi, iż zakażenie pochodzi z innych źródeł niż zaniedbania pracowników ochrony zdrowia, ciężar dowodu przenosi się ze strony pacjenta na podmiot leczni$\mathrm{czy}^{42}$. Wówczas to świadczeniodawca powinien wykazać, że istniało wysokie prawdopodobieństwo innej przyczyny powstania zakażenia. Samo zaprzeczanie dowodom i okolicznościom działającym na niekorzyść podmiotu leczniczego nie będzie stanowiło przeciwdowodu ${ }^{43}$. Z kolei podnoszenie przez podmiot leczniczy, że zakażenie było „efektem kolonizacji związanej z higieną osobistą chorego" (...), nie może prowadzić do podważenia wskazanego domniemania. Stan zdrowia pacjenta, który jest leczony od kilku miesięcy w podmiocie leczniczym, powinien być znany pracownikom medycznym sprawującym nad nim opiekę. Fakt, że pacjent jest niesamodzielny, leżący, wymaga obsługi higienicznej, winien skutkować odpowiednim zabezpieczeniem stanu zdrowia pacjenta przed ewentualnym zakażeniem. Za niewłaściwy stan higieniczny pacjenta $\mathrm{w}$ takich warunkach odpowiedzialność ponosi świadczeniodawca. Ponadto podjęcie właściwego leczenia po stwierdzeniu zakażenia i zastosowanie dopiero wówczas właściwego reżimu sanitarnego, nie wyłącza przyjęcia co najmniej braku należytej staranności po stronie pracowników podmiotu leczniczego, który doprowadził do zakażenia poszkodowanego ${ }^{44}$.

${ }^{39}$ Wyrok Sądu Apelacyjnego w Łodzi z dnia 6 listopada 2014 r., I ACa 621/14, LEX 1623923.

40 G. Ziółkowski, I. Pawłowska, T. Bielecki, Prawo a zakażenia, „Pielęgniarka Epidemiologiczna" 2016, nr 2, s. 27.

${ }^{41}$ Wyrok Sądu Apelacyjnego w Łodzi z dnia 6 listopada 2014 r., I ACa 621/14, LEX 1623923.

42 Tamże.

${ }^{43}$ M. Nesterowicz, Glosa do wyroku Sąu Apelacyjnego we Wroctawiu z dnia 28 kwietnia 1998 r., I ACa 309/98 - dowody w procesie o zakażenie pacjenta choroba zakaźna, [w:] M. Nesterowicz, Prawo medyczne. Komentarze i glosy do orzeczeń sądowych, Warszawa 2014, s. 305.

${ }^{44}$ Wyrok Sądu Apelacyjnego w Lublinie z dnia 19 czerwca 2013 r., I ACa 727/12, LEX 1342295. 
Jak wskazano powyżej, okolicznością obciążającą podmiot leczniczy jest stwierdzenie braków w zaopatrzeniu w sprzęt jednorazowego użytku, niesprawność aparatury sterylizacyjnej, nadmierne zagęszczenie pacjentów, czyli jednym słowem, niezachowanie standardów sanitarno-epidemiologicznych ${ }^{45}$.

Ustalenie adekwatnego związku przyczynowo-skutkowego wymaga przyjęcia pewnej konstrukcji myślowej, której założeniem jest stwierdzenie, że gdyby nie zaistniało zawinione działanie lub zaniechanie szpitala, to nie byłoby zakażenia szpitalnego. Ustalenie, że do zakażenia doszło wskutek zawinionego działania świadczeniodawcy, wymaga wykazania, że zakażenie było wynikiem braku należytej staranności wymaganej od pracownika medycznego czy też błędu organizacyjnego przejawiającego się m.in. w niezapewnieniu właściwego sprzętu, środków dezynfekcyjnych, czy też wykonywanie czynności medycznej przy braku wymaganych przez pracownika kwalifikacji. Za zachowanie niewłaściwe uznaje się bowiem działanie lub zaniechanie stanowiące naruszenie obowiązujących reguł wynikających z zasad wiedzy medycznej, doświadczenia i deontologii zawodowej ${ }^{46}$. Zachowanie pracowników medycznych musi być obiektywnie bezprawne i subiektywnie zawinione, wyrażać się w niewiedzy pracowników medycznych, nieostrożności w ich postępowaniu, nieuwadze bądź też niedbalstwie polegającym na niedołożeniu pewnej miary staranności. Obowiązkiem całego personelu medycznego zakładu leczniczego jest dołożenie należytej staranności w leczeniu każdego pacjenta.

\section{Podsumowanie}

Związek przyczynowo-skutkowy jest konieczną przesłanką powstania odpowiedzialności, a brak przyczynowości powoduje, że nawet ewentualna ocena zachowania strony pozwanej jako bezprawnego i zawinionego nie może doprowadzić do uznania jej odpowiedzialności za szkodę. Ów

${ }^{45}$ I. Wrześniewska-Wal, Postępowanie dowodowe..., s. 98.

${ }^{46}$ R. Patryn, Określenie zasady postępowania lekarza z należyta starannościa z płaszczyzny orzecznictwa sąowego, „Prawo i Medycyna” 2017, nr 2(47 Vol. 14), http://www.prawoimedycyna.pl/sklep/1067/okreslenie-zasady-postepowanialekarza-z-nalezyta-starannoscia-z-plaszczyzny-orzecznictwa-sadowego--pim-47 [dostęp: 20.09.2017 r.]. 
związek przyczynowy musi nadto cechować co najmniej wysoki stopień prawdopodobieństwa. W procesach medycznych wymaganie całkowitej pewności w każdej sytuacji byłoby trudne do spełnienia. W sprawach o zakażenie szpitalne wręcz nie jest na ogół możliwe stwierdzenie z całkowitą pewnością, że przyczynę zakażenia stanowiło konkretne zdarzenie, zwłaszcza że coraz częściej zwraca się uwagę na udział zakażeń endogennych i czynniki ryzyka zależne od pacjenta. Dlatego sądy ograniczają się do ustalenia tylko wysokiego prawdopodobieństwa związku przyczynowego. W dowodzeniu korzystają też z domniemania faktycznego oraz dowodu prima facie.

Słowa kluczowe: zakażenie szpitalne, związek przyczynowo-skutkowy, ciężar dowodu, domniemanie faktyczne.

\section{Bibliografia}

Białkowski B., Dowód prima facie w postępowaniu cywilnym dotyczacym szkód powstatych w zwiazku z leczeniem, https://repozytorium.amu.edu.pl/bitstream/10593/13845/1/Dowod_pirma_facie_w_postepowaniu_cywilnym_dotyczacym_szkod_powstalych_w_zwiazku_z_leczeniem.pdf.

Dolecki H., Wiśniewski T. (red.), Kodeks postępowania cywilnego. Komentarz, t. I, art. 1-366, Lex 2013.

Ereciński T. (red.), Kodeks postępowania cywilnego. Komentarz, t. II, Postępowanie rozpoznawcze, Warszawa 2016.

Ereciński T., [w:] T. Ereciński (red.), Kodeks postępowania cywilnego. Komentarz, t. I, Postępowanie rozpoznawcze, Warszawa 2012.

Jakubecki A. (red.), Kodeks postępowania cywilnego, t. I, Komentarz do art. 1-729, Warszawa 2017.

Janiszewska B., Praktyka sądowa w sprawach cywilnych o zakażenia szpitalne (dowodzenie przesłanek odpowiedzialności oraz roszczenia przysługujace pacjentowi - część I), „Prawo i Medycyna”,

http://www.prawoimedycyna.pl/index.php?str=artykul\&id=225.

Nesterowicz M., Ciężar dowodu winy w procesach lekarskich, PiP 1968, nr 4-5.

Nesterowicz M., Glosa do wyroku Sadu Apelacyjnego we Wrocławiu z dnia 28 kwietnia 1998 r., I ACa 309/98 - dowody w procesie o zakażenie pacjenta choroba zakaźna, [w:] Nesterowicz M., Odpowiedzialność cywilna zakładu leczniczego za bezpieczeństwo pacjenta podczas hospitalizacji, PiP 2001, nr 3.

Nesterowicz M., Prawo medyczne. Komentarze i glosy do orzeczeń sadowych, Warszawa 2014.

Nesterowicz M., Prawo medyczne, Toruń 2013. 
Nesterowicz M., Prawo medyczne. Komentarze i glosy do orzeczeń sądowych, Warszawa 2014.

Patryn R., Określenie zasady postępowania lekarza z należyta starannościa z płaszczyzny orzecznictwa sąowego, „Prawo i Medycyna” 2017, nr 2(47 Vol. 14), http://www.prawoimedycyna.pl/sklep/1067/okreslenie-zasady-postepowanialekarza-z-nalezyta-starannoscia-z-plaszczyzny-orzecznictwa-sadowego--pim-47.

Rzetecka-Gil A., Kodeks cywilny. Komentarz. Zobowiązania - Część ogólna, LEX/ el 2011, uwaga 3 do art. 361 k.c.

Sośniak M., Zagadnienie zwiazku przyczynowego a dowód prima facie w procesach lekarskich, Księga pamiątkowa ku czci Kamila Stefki, Warszawa-Wrocław 1967.

Śliwka M., Ciężar dowodu w procesach medycznych - między domniemaniami faktycznymi a dowodem prima facie II. Domniemania faktyczne a dowód prima facie, „Archiwum Medycyny Sądowej i Kryminologii" 2004, nr 1.

Wąsik D., Wąsik N., Sygit B., Dubiel M., Zakażenie endogenne a odpowiedzialność cywilna szpitala - studium przypadku, „Archiwum Medycyny Sądowej i Kryminologii" 2014, nr 64(3).

Wrześniewska-Wal I., Postępowanie dowodowe w zakażeniach szpitalnych, „Medical Maestro Magazine" 2015, nr 1.

Ziółkowski G., Pawłowska I., Bielecki T., Prawo a zakażenia, „Pielęgniarka Epidemiologiczna" 2016, nr 2.

\section{Wykaz orzecznictwa}

Wyrok Sądu Najwyższego z dnia 14 stycznia 2016 r., I CSK 1031/14, LEX nr 1991132.

Wyrok Sądu Najwyższego z dnia 17 maja 2007 r., III CSK 429/06, niepubl.

Wyrok Sądu Najwyższego z dnia 4 listopada 2005 r., V CK 182/05, LEX nr 180901.

Wyrok Sądu Najwyższego z dnia 19 lutego 2002 r., IV CKN 718/00, niepubl. Wyrok Sądu Najwyższego z dnia 13 czerwca 2000 r., V CKN 34/00, niepubl. Wyrok Sądu Najwyższego z dnia 22 stycznia 1998 r., II UKN 465/97, OSNP z 1999 r., nr 1, poz. 24.

Wyrok Sądu Najwyższego z dnia 11 stycznia 1972 r., I CR 516/71, OSNCP, nr 9, poz. 159.

Wyrok Sądu Najwyższego z dnia 7 czerwca 1969 r., II CR 165/69, OSPiKA z 1969 r., nr 7-8, poz. 155.

Wyrok Sądu Najwyższego z dnia 5 lipca 1967 r., I PR 74/67, OSN z 1968 r., nr 2, poz. 26.

Wyrok Sądy Apelacyjnego w Krakowie z dnia 3 marca 2016 r., I ACa 1661/15, LEX nr 2004524.

Wyrok Sądu Apelacyjnego w Szczecinie z dnia 28 kwietnia 2015 r., I ACa 323/13, LEX nr 1782045. 
Wyrok Sądu Apelacyjnego w Łodzi z dnia 6 listopada 2014 r., I ACa 621/14, LEX 1623923.

Wyrok Sądu Apelacyjnego w Warszawie z dnia 3 czerwca 2014 r., I ACa 1494/13, LEX nr 1493819.

Wyrok Sądu Apelacyjnego w Szczecinie z dnia 10 kwietnia 2014 r., I ACa 22/14, LEX nr 1466926.

Wyrok Sądu Apelacyjnego w Lublinie z dnia 19 czerwca 2013 r., I ACa 727/12, LEX nr 1342295.

Wyrok Sądu Apelacyjnego w Poznaniu z dnia 10 sierpnia 2011 r., I ACa 1082/10, LEX nr 898633.

Wyrok Sądu Apelacyjnego w Warszawie z dnia 29 marca 2011 r., I ACa 917/10, LEX nr 836914.

\section{CAUSE-AND EFFECT RELATIONSHIP AS THE PREMISE OF PROVIDER'S LIABILITY FOR HOSPITAL-ACQUIRED INFECTION}

\section{$\mathrm{S} \mathbf{u} \mathbf{m} \mathbf{m}$ a $\mathbf{r} \mathbf{y}$}

Cause-and-effect relationship is one of the premises of a provider's liability for a hospital-acquired infection. However, the evidentiary difficulties involved in dealing with the damage caused to a patient by a hospital infection are both important and still pose an issue. The legislator has adopted a precise definition in which hospital infection remains in a functional and adequate cause-and-effect relationship with the provision of medical care. In a civil process, the injured person must be able to prove and establish a causal link between the fault of the subject and the injury.

In medical trials, the court may, after considering the circumstances of the case, acknowledge probability to be sufficiently high, without requiring a strict and certain proof of how the organism was infected, because such proof is often impossible to obtain for biological reasons. Therefore, if there is no possibility to prove the cause-and-effect relationship between infection and the damage in the form of disease progression, as a result of the present state of medical knowledge, it should be considered at the level of Art. 6 and Art. 361 paragraph 1 of the Civil Code. The above limitations of the evidence and the nature of the cases in which they occur also result in a specific displacement of the burden of proof. In the case of unrealistic strict requirements, the means by which the infection has entered the body, if the defendant claims that, despite the established condition, the infection is from other sources, the burden of proof is shifted to the defendant, that is, the therapeutic agent.

Key words: hospital infection, cause-and-effect relationship, burden of proof, actual presumption. 


\title{
ДОКАЗЫВАНИЕ ПРИЧИННО-СДЕДСТВЕННОЙ СВЯЗИ В ДЕДАХ О БОЛЬНИЧНЫХ ИНФЕКЦИЯХ
}

\author{
P е 3 ю м е
}

Причинно-следственная связь является одной из предпосылок ответственности лица, которое предоставляет услуги, за больничную инфекцию. Однако проблема при доказательстве, выступающая в делах о возмещения вреда, причиненного пациенту в связи с больничной инфекцией, представляют важный и, одновременно, постоянный проблематичный вопрос. Законодатель принял соответствующее понятие, в связи с которым больничная инфекция является в функциональной и адекватной причинно-следственной связи с предоставлением медицинских услуг. В гражданском процессе пострадавший должен обосновать и доказать возникновение причинной связи между виной медицинского субъекта и возникшим вредом. В медицинских процессах суд может после обдумывания совокупности обстоятельств дела признать достаточно высокий степень вероятности, не требуя убедителыных и надежных доказательств, каким способом организм были инфицирован, так как данное доказательство - учитывая свойства биологических процессов - часто не является возможным к осуществлению. Следовательно, если отсутствуют возможности предоставить убедительного доказательства причинно-следственной связи между инфекцией и вредом в виде развития болезни, которая является результатом нынешнего состояния медицинских знаний, должно быть обосновано на основании ст. 6 и ст. 361 § 1 ГК. Вышеупомянутые доказательные ограничения и характер дел, в которых также выступают своеобразным перемещением бремя доказательства. В случае нереального к осуществлению требования предоставить убедительные доводы, каким способом инфекция возникла в организме, если ответчик утверждает, что несмотря на сложившееся положение дела, инфекция возникла из других источников, бремя доказательства передвигается на ответчика, то есть на медицинский субъект.

Ключевые слова: больничная инфекция, причинно-следственная связь, бремя доказательства, фактическая презумпция. 